\title{
Comprehensive Assessment on the Environmental Conditions of Abandoned and Inactive Mines in the Philippines
}

\author{
Jessie Samaniego ${ }^{1, *}$, Cris Reven Gibaga ${ }^{1}$, Alexandria Tanciongco ${ }^{1}$, Rasty Rastrullo ${ }^{1}$, Norman Mendoza ${ }^{1}$, and \\ Charles Darwin Racadio ${ }^{1}$
}

${ }^{1}$ Department of Science and Technology, Philippine Nuclear Research Institute, Commonwealth Ave., Quezon City, 1101, Philippines

*Corresponding author: josamaniego@pnri.dost.gov.ph

\author{
KEYWORDS \\ Abandoned mines \\ Inactive mines \\ Mine rehabilitation \\ Risk assessment \\ Philippines \\ SUBMITTED 5 June 2020 \\ REVISED 29 July 2020 \\ ACCEPTED 29 July 2020
}

\begin{abstract}
Most abandoned and inactive mines in the Philippines pose high risks to human health and the environment due to the disturbed and exposed heavy metal-laden soils and sediments and waterfilled open pit mines. Establishing these mines' environmental conditions remains a challenge as it requires time, effort, resources, and faces a lack of funding as the economic phase of the mine has already ceased. In order to contribute to the solution on the assessment of abandoned and inactive mines, integrated methods with combined essential testing, sampling, and analyses of different environmental media present in the mine site are suggested in this paper. On-site and laboratory methods include analyses for water (surface water and groundwater characterization, quality assessment, and environmental isotope tracers), soils and sediments (heavy and trace metals, anomalous elements, erosion, and nutrient availability), air quality, and radiometric survey. These methods can be classified as rapid with complete data, and information can be gathered to support a health risk assessment in the area, as well as used as a guide for rehabilitation prioritization of the abandoned mines.
\end{abstract}

(c) The Author(s) 2020. This article is distributed under a Creative Commons Attribution-ShareAlike 4.0 International license.

\section{INTRODUCTION}

Abandoned mines are those that have a mining lease contract or mineral agreement but were not operated within a reasonable amount of time, or otherwise have closed without proper decommissioning, with a mining contractor that cannot be found or is not willing to carry out the work of rehabilitation. Almost all abandoned and inactive mines pose high risks to human health and the environment, due to the disturbed and exposed heavy metal-laden soils and sediments and water-filled open pit mines (Figure 1). People living in abandoned mine areas may directly ingest heavy metal-contaminated soils through plants and vegetables or consume contaminated water. Contaminated soils can be leached out and transported by precipitation runoff and can be eroded to the rivers and lakes and eventually deposited into the nearby coastal areas that serve as the sink for such pollutants. In coastal environments, heavy metals may become available and bio-accumulate to biota, causing biomagnification of the contaminants as it ultimately enters the food chain (Akcali and Kucuksezgin 2011; Ali et al. 2019). Unvegetated soils and tailings in a mining area contribute to the pollution in this area, brought about by the particle-bound heavy metals suspended in the air, which can be inhaled by humans living near the site (Fortoul et al. 2015). Contaminated soils and water in abandoned mines have also a big impact on local wildlife, as these metal ions are bioavailable to animal body organs and tissues and can cause chronic illnesses (Lim et al. 2008).

Abandoned and inactive mine sites have stockpiled mine wastes and tailings that are detrimental to natural plant growth due to their physico-chemical characteristics of high $\mathrm{pH}$, high salinity, low water retention capacity, high heavy metal concentrations, and deficiency in soil organic matter and fertility (Favas et al. 2018; Wang et al. 2017; Samaniego et al. 2020). The latter is the biggest challenge in revegetation and rehabilitation of the mine waste stockpiles and exposed slopes.

Another consideration in the evaluation of the usability of abanadoned mines is the radiation and radioactivity in the area. Soils and rock in mining areas (e.g. copper mine) may contain naturally occurring radioactive materials (NORM) such as potassium (K), uranium (U), thorium (Th), and radium (Ra). Mining and extraction of copper and other critical metals by common surface methods can concentrate and expose radionuclides in the waste rocks or tailings. Another extraction method, known as in-situ leaching, can transport $U$ and Th into the groundwater or surface water of the site. Both methods expose and/or concentrate NORM, transforming it into technologically enhanced naturally occurring radioactive materials (TENORM). These can further alter the properties of radioactive materials by processes, benefiting or disturbing the natural properties that can increase the potential for human and/or environmental exposures (US EPA 2019).

Around the world, full characterization of the environmental hazards posed by abandoned and inactive mines given the typical geographic extent of its operations and potential impacts, requires time, effort and resources. Rehabilitation of these abandoned mines is problematic because of the lack of criteria and standards to be followed, unclear parties to be held responsible, and lack of funding as the 


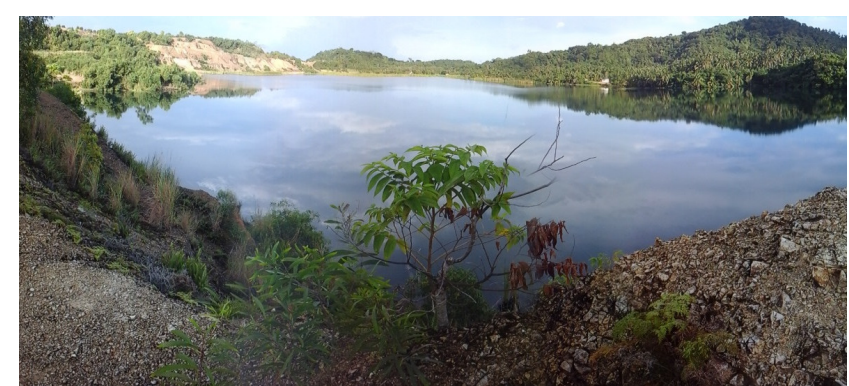

(a)

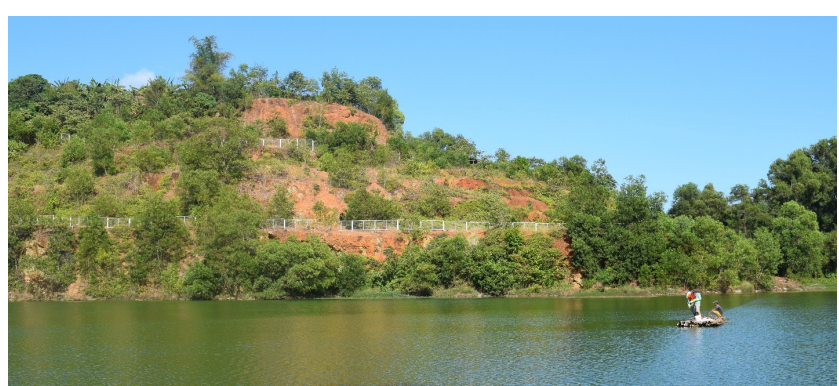

(b)

FIGURE 1. Abandoned mines in the Philippines. (a) Ino and Capayang pit lake and mined-out area in Mogpog, Marinduque; (b) Palawan Quicksilver Mines, Inc. pit lake and stocked mine waste calcines in Puerto Princesa City.

economic phase of the mine already ceased. There are two main types of hazard scenario assessments associated with abandoned and inactive mines with full characterization; these are: (a) those related to safety (e.g. accidents, falls, slides, etc.), which require direct exposure to the idle and dilapidated equipment and buildings of an abandoned mining site and has immediate effect, and (b) those related to the contamination that an abandoned mine can generate and how it is spread in different environmental media (e.g. soil, air, or water) and reach receptors (e.g. humans) and produce undesirable effects (Hasheela et al. 2014).

Environmental assessment methodologies employed in abandoned and inactive mines tend only to focus on the contamination that an abandoned mine can generate and how it is spread in different environmental media, such as soil, air, or water, and whether it reaches receptors. Some activities in these assessments are often incomplete and mainly based on land-use, the visual appearance of the site, water pollution, water availability and hydrological impacts, air pollution, radiation and geological hazards, effects on vegetation and biodiversity, and quality of life and cultural values. Data and observations gathered using the above methods are used in health risk assessments that may be affected by inadequate data being inputted into their models. Unreliable data may also come from improper sample collection, equipment usage, or laboratory analyses.

In order to contribute to the solution on the assessment of abandoned and inactive mines, an integrated methods approach with combined essential testing, sampling, and analyses of different environmental media present in the post-mined site is presented in this paper. These methods can be classified as rapid with complete data and information able to be gathered to support the health risk assessment in the area and may likewise be used as a guide for rehabilitation prioritization of the abandoned mines.

\section{ABANDONED AND INACTIVE MINES IN THE PHILIPPINES}

Currently, there are twenty-seven (27) abandoned and inactive mines in the Philippines as characterized by the Mines and Geosciences Bureau (MGB) (Aggangan et al. 2019). The minerals extracted from these mines were gold, copper, chromite, mercury, silica, iron, pyrite, and marble. Most of the copper mines, such as the Kennon Mine of Black Mountain, the Tapian and Ino-Capayang Mines, Sto. Nino Mine, and Boneng-Lobo Mine of Western Minolco, started operations in the 1960s due to the full-blown boom in the copper industry, which declined in the latter part of 1970s due to a high inflationary trend. The closure of several copper mines continued due to the decline in copper prices globally up until 1990s. Similar trends occurred for other metal- lic mineral commodities like gold, mercury, and chromite. Since it was only in 1995 that a law was passed governing all mining activities in the Philippines (i.e. Philippine Mining Act of 1995), mines that ceased operations before 1995 were mostly abandoned without rehabilitation. Some of these mines, up until now, are still unremediated. The regulations and guidelines regarding mine rehabilitation and decommissioning were incorporated only in 1996, as the rules and regulations of the Mining Act were implemented, while the active pursuance to examine the conditions of areas with abandoned mine sites only came later. In early 2001, MGB commissioned Tetra Tech EM Inc. to undertake a preliminary site assessment of twenty-one (21) selected abandoned mines in the country (Aggangan et al. 2019; Samaniego et al. 2019). The result of the semi-detailed assessment showed that all abandoned mine sites pose environmental risks of varying degrees-from unstable tailings ponds, toxic contaminants in soil, and water which may harm human, aquatic, terrestrial, and wildlife.

After the assessment of abandoned and inactive mines, MGB started to conduct further assessments of environmental conditions in several mines and subsequently started their rehabilitation by planting vegetation and trees. These mines are the Philippine Pyrite Mines in Bagacay, Samar (Bueno 2018), Ino and Capayang Mines in Mogpog, Marinduque (Aggangan et al. 2019; Lanot et al. 2020), and Palawan Quicksilver Mines, Inc. (Samaniego et al. 2019).

In an archipelago, the marine environment can be vulnerable to increasing heavy metal pollution stemming from abandoned mines. One such case is in the suspended nickel laterite mine in Manicani Island in Eastern Samar (Holden 2012). The concentration of lead, nickel, and copper in the nearby seawater were all above the allowable limits set by the Department of Environment and Natural Resources (DENR) and United States Environmental Protection Agency (US EPA), while nickel was found to be the highest in a certain macroalgae species (Corales-Ultra et al. 2019). Accumulation of heavy metals in marine sediments were also observed near the tailings spill of Marcopper Mine in Marinduque island. Elevated amounts of $\mathrm{Cu}, \mathrm{Mn}, \mathrm{Pb}$, and Zn were observed in marine core sediments with peak concentrations corresponding to the spill, but contamination was still persistent in surface sediments even some years after the incident due to the reworking of grains (David 2002).

\section{ASSESSMENT OF ENVIRONMENTAL CONDITIONS OF ABANDONED AND INACTIVE MINES}

\subsection{Initial stages}

The proposed integrated method for rapid assessment of the environmental conditions of abandoned and inactive 
mines are summarized in Figure 2. The foremost step starts with the site information review. The activities in this stage include a review of the previous site's inspection reports, published literature and research articles, and technical reports from the owner of the mine. The next is a site inventory, which is the familiarization of the mine location as well as field verification of site characteristics and conditions. The initial site evaluation is the first site visit to apply the gathered existing information of the site. This activity will verify the bodies of water, soil, vegetation state, and even the availability of water wells. It will also determine the sequence of the methods to be followed during the subsequent detailed site evaluation.

\subsection{Environmental assessment process}

Environmental assessment processes encompass the majority of the activities for the proposed integrated methods. These include sampling and in situ analyses of environmental media-air, surface water, groundwater, soil, sediments and rocks in the area.

The first procedure is the surface water sampling and analyses, with activities that include physico-chemical parameter determination using a multi-parameter water quality meter or equivalent. Water samples will be collected from the site and be brought to a laboratory for the analysis of other parameters (e.g. color, suspended solids) and heavy metal concentrations. Analysis of heavy metal concentrations shall use an atomic absorption spectrometer (AAS) or inductively coupled plasma-optical emission spectrometer (ICP-OES) or equivalent. Analysis of heavy metals must give emphasis on the mined metal and its associated accessory metals that are anomalous in the mine site.

Groundwater analysis includes an inventory of wells that can be used as sampling wells and, if not available, drilling of new wells is recommended. Groundwater samples shall be collected from the deep and shallow wells and shall be analyzed for major cations and anions to determine the water's general hydrochemical changes. Analysis of heavy metal concentrations in groundwater shall also use an ICP-OES or equivalent. Analysis of heavy metal must give emphasis on the mined metal and its associated accessory metals that are anomalous in the mine site.

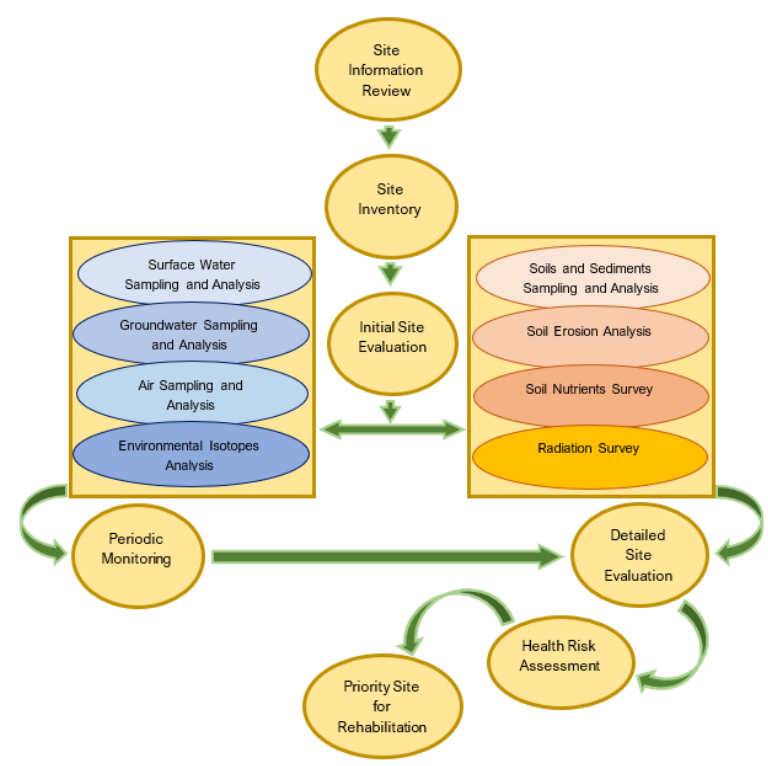

FIGURE 2. Process flow chart of rapid environmental assessment of abandoned and inactive mines.
Separate water samples shall be collected from the sampling wells and surface water that will be used for the environmental isotope analysis. Rainwater shall also be collected near the mining site to establish a local meteoric water line (LMWL). Groundwater samples will be analyzed for the isotopes tritium $\left({ }^{3} \mathrm{H}\right)$, deuterium $\left({ }^{2} \mathrm{H}\right)$, and oxygen-18 $\left({ }^{18} \mathrm{O}\right)$. These isotopes will provide important groundwater information, such as origin and general age of the groundwater (Hillegonds et al. 2014), as well as determine if there is mixing of different water molecules from different inputs in the aquifer. Water samples will further undergo low-level tritium analysis via an electrolytic enrichment system and low-level liquid scintillation spectrometry or an equivalent method. Measurement of ${ }^{2} \mathrm{H}$ and ${ }^{18} \mathrm{O}$ ratios of hydrogen and oxygen will be carried out using an isotopic water analyzer or equivalent.

Air sampling can be conducted using a high volume air sampler or equivalent to determine the total suspended particulates. Particulates trapped in the filter can be analyzed for heavy metals using x-ray fluorescence or equivalent method, or digesting the used filter and analyzing it using an AAS or equivalent. Specific volatile metals in the air, such as mercury (Hg), can be measured using a personal air pump with an adsorbent that will be analyzed in a mercury analyzer. Mercury can also be measured using fieldportable mercury detectors or their equivalent.

Sampling of soil, rocks, and sediments will be conducted to determine the anomalous heavy metals and trace metals present in the mined-out area and its vicinity. Soil shall be collected from the top soil while the bottom sediment from a river, lake, and/or sea shall be collected using a sediment grab sampler. Concentration of heavy metals, trace metals, rare earth elements, and NORM from the soil and sediment samples shall be analyzed using inductively coupled plasma-mass spectrometry (ICP-MS) or an equivalent. A spatial distribution map of anomalous heavy metals shall be generated using the measured concentrations of soil, rocks, and sediments.

Soil erosion analysis will be performed with the use of modelling, based on the universal soil loss equation (USLE) or the use of radioisotopes Caesium-137 $\left({ }^{137} \mathrm{Cs}\right)$ and Lead$210\left({ }^{210} \mathrm{~Pb}\right)$ as tracers for soil erosion and sedimentation in the study area (Matisoff 2014).

A radiation survey in the abandoned and inactive mine is necessary to measure the radiation emanating from mine wastes, tailings, and the ground. The survey can be done using a handheld gamma-ray spectrometer or equivalent tool. The results of this survey can be presented in the form of radiological maps and NORM spatial distribution maps. The radiation dose rate and annual dose to the exposed humans will be calculated to assess possible health concerns.

A soil nutrient survey shall be carried out during soil and sediment sampling, wherein top-soil samples will be analyzed using a portable multi-element analyzer or its equivalent, which can analyze important soil nutrients, such as $\mathrm{N}, \mathrm{P}, \mathrm{K}$, and other micronutrients.

\subsection{Risk assessment process}

Specific sampling and analysis (surface water, groundwater, environmental isotopes, air) shall be done for at least twoseason (wet and dry) periodic monitoring to determine the temporal variations of the analyzed environmental samples. The results of the periodic monitoring will be added to the detailed site evaluation process, including specific sampling, analyses, and surveys (soil and sediments, soil erosion, radiation, soil nutrients). The detailed site evaluation 
will focus on the overall inter-relationship of the specific sampling, analysis, and surveys done to determine the total characteristic of the abandoned and inactive mine. The results of the detailed site evaluation will be used as input for the subsequent health risk assessment of the mine area. This risk assessment may be in the form of carcinogenic and non-carcinogenic heavy metals measured in surface water, groundwater, air, soil, and sediments, while a radiological risk assessment will be performed using the data from the radiation survey. The outcome of these assessments can be considered as the main basis for the prioritization of rehabilitation. A detailed assessment of the different environmental media related to the mine site will narrow down the particular portion that needs more attention and focus during rehabilitation.

\section{CASE STUDY IN ABANDONED MERCURY MINE}

The abandoned mercury (Hg) mine site in Puerto Princesa City (Figure 3), which was operated by Palawan Quicksilver Mines, Inc. (PQMI) from 1953 to 1976, has been previously identified as the possible cause for the recent $\mathrm{Hg}$ poisoning cases among the residents in its vicinity (Gray et al. 2003). To verify human exposure pathways of $\mathrm{Hg}$ in the area, a comprehensive analysis was performed on the $\mathrm{Hg}$ from different environmental samples (surface water, groundwater, environmental isotopes, air, soil, and sediment) collected from the vicinity of the abandoned mine area.

The results showed that the physico-chemical characteristics of different surface waters were generally within the Philippines water quality guidelines of DENR (2016). Mercury concentrations in the pit lake and river were not detected while low $\mathrm{Hg}$ concentrations were measured in coastal water near the Honda Bay wharf $(0.001 \mathrm{mg} / \mathrm{L})$ and hotspring $(<0.0004 \mathrm{mg} / \mathrm{L})$. The very low concentrations of Hg in Tagburos River and PQMI lake $(<0.20 \mu \mathrm{g} / \mathrm{L})$ can be associated with the low solubility of $\mathrm{Hg}$ compounds (mostly cinnabar) from the tailings and sediments.

All measured THg concentrations from the groundwater samples collected from existing deep wells, drilled boreholes, and hand water pumps were below the WHO limits and Philippines standards for drinking water of $1 \mu \mathrm{g} / \mathrm{L}$. Based on the matrix provided by Motzer (2007), tritium levels of 0.28-0.51 tritium units (TU) indicated the groundwater's age to be sub-modern water (recharge prior to the 1950s). Due to the long mean residence time of groundwater, it is less vulnerable to contamination. Stable isotopes

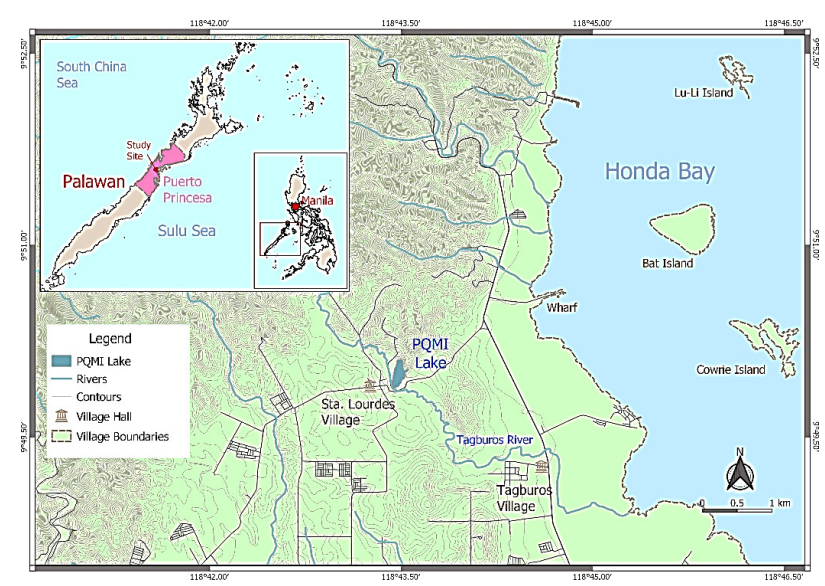

FIGURE 3. Map of the study site showing the rivers, pit lake, and Honda Bay, with a map of the Philippines and Palawan island (inset). $\left(\delta^{2} \mathrm{H}\right.$ and $\left.\delta^{18} \mathrm{O}\right)$ measured in the groundwater and river water in the PQMI area also showed that these waters were recharged by local precipitation and originated from meteoric water.

Total $\mathrm{Hg}$ concentrations $\left(2,035-2,138 \mathrm{ng} / \mathrm{m}^{3}\right)$ in the air during the dry season were measured at the mine waste calcine deposits and exposed natural soil and rock outcrops, northeast of the pit lake. In other areas, concentrations were relatively lower but still high compared with the global background of gaseous $\mathrm{Hg}$, which is set at $1.0-3.0 \mathrm{ng} / \mathrm{m}^{3}$ (Sprovieri et al. 2010). The elevated levels of $\mathrm{Hg}$ levels can be attributed to the waste calcine that releases gaseous $\mathrm{Hg}$ and particle-bound $\mathrm{Hg}$ from the exposed areas, contributing to human risk.

The results of $\mathrm{Hg}$ analyses in soils and sediments followed a similar contamination pattern to that from other reported Hg mine sites worldwide (Gray et al. 2002; Qiu et al. 2005, 2006; Gionfriddo et al. 2015). The main pathway of the reported $\mathrm{Hg}$ contamination in the area was caused by sediment transport from two main sources, namely: (1) the calcines stockpiled at the shore of the pit lake and nearby area, and (2) Honda Bay wharf. Mercury levels in the wharf were found to be similar to that of mine waste, confirming construction of the wharf using calcine from the PQMI site. Other areas were relatively less contaminated, but still exceeded the global background. The elevated Hg concentration in Honda Bay sediments may undergo methylation and enter the food chain.

Naturally occurring radioactive materials ( $\mathrm{U}$ and $\mathrm{Th}$ ) were measured in very low concentrations, since Puerto Princesa city is underlain with ultramafic rock. Radiation emitting from this mine has no potential harm for human and/or environmental exposures.

Mercury and heavy metal concentrations measured in soil and sediments were used for the health risk assessment model generated by the US EPA to evaluate the health risk of adults living in the vicinity of the abandoned mine area (US EPA 2002; US EPA 2011). This assessment focused on non-carcinogenic risks caused by the contaminant of concern, which is $\mathrm{Hg}$. Based on the calculation, $\mathrm{Hg}$ was the largest contributor to health risk with a hazard index (HI) of $>1$, which is beyond acceptable limits. Exposure pathways were mainly via ingestion of soil particles followed by dermal absorption. Other heavy metals had $\mathrm{HI}$ values of $<1$. Elevated $\mathrm{Hg}$ concentrations in the air contributed the most to the overall high $\mathrm{HI}$ in the mined-out area. The results revealed that there is a risk of potential health problems to the residents in the vicinity of the abandoned $\mathrm{Hg}$ mine site. Mining rehabilitation activities, such as revegetation to reduce soil erosion and soil particle suspension, need to be implemented based on the results of this study.

\section{CONCLUSIONS}

Presented here is a set of methods for the rapid assessment of environmental conditions of abandoned and inactive mine sites, to be used as a guide to the rehabilitation or rehabilitation prioritization of these sites. The methods include analyses of water (surface water and groundwater characterization, quality assessment, and environmental isotope tracers), soils and sediments (heavy and trace metals, anomalous metals, erosion, and nutrient availability), and air quality, as well as radiometric surveys. These methods can be done in situ using handheld instruments and equipment while some environmental samples can be brought to a laboratory for further analysis. The results of site evaluations can be used as the inputs of subsequent 
health risk assessments, which may be in the form of carcinogenic and non-carcinogenic heavy metals measured in surface water, groundwater, air, soil, and sediments, while radiological risk assessments can be performed using radiation survey data. A detailed assessment of the different environmental media related to a mine site will narrow down which particular portion needs more attention and focus during rehabilitation. This model has been employed effectively in a case study of an abandoned mercury mine site in the island of Palawan, Philippines.

\section{ACKNOWLEDGMENTS}

The authors acknowledge the Department of Science and Technology; the Philippine Council for Industry, Energy, and Emerging Technology Research and Development (DOST-PCIEERD); and the Department of Science and Technology - Grants-in-Aid Program for the grant.

\section{AUTHORS' CONTRIBUTIONS}

All authors wrote the manuscript, and read and approved the final version of the manuscript.

\section{COMPETING INTERESTS}

The authors declare that there is no conflict or competing of interests regarding the publication of this manuscript.

\section{REFERENCES}

Aggangan NS, Anarna JA, Cadiz NM. 2019. Tree legume - microbial symbiosis and other soil amendments as rehabilitation strategies in mine tailings in the Philippines. Philipp J Sci. 148(3):481-491.

Akcali I, Kucuksezgin F. 2011. A biomonitoring study: heavy metals in macroalgae from eastern Aegean coastal areas. Mar Pollut Bull. 62(3):637-645. doi:10.1016/j.marp olbul.2010.12.021.

Ali H, Khan E, Ilahi I. 2019. Environmental chemistry and ecotoxicology of hazardous heavy metals: environmental persistence, toxicity, and bioaccumulation. J Chem. 2019. doi:10.1155/2019/6730305.

Bueno M. 2018. Evaluation of abandoned mine lands rehabilitation: the case of Bagacay mine, Western Samar, Philippines [Master's thesis]. [Tokyo]: University of Tokyo.

Corales-Ultra OG, Peja RP, Casas EV. 2019. Baseline study on the levels of heavy metals in seawater and macroalgae near an abandoned mine in Manicani, Guiuan, Eastern Samar, Philippines. Mar Pollut Bull. 149:110549. doi:10.1 016/j.marpolbul.2019.110549.

David CP. 2002. Heavy metal concentrations in marine sediments impacted by a mine-tailings spill, Marinduque Island, Philippines. Environ Geol. 42(8):955-965. doi: 10.1007/s00254-002-0601-4.

[DENR] Department of Environment and Natural Resources. 2016. Water quality guidelines and general effluent standards of 2016. Quezon City: Department of Environment and Natural Resources. https://pab.em b.gov.ph/wp-content/uploads/2017/07/DAO-2016 - 08-WQG-and-GES.pdf.

Favas PJdC, Martino LE, Prasad MNV. 2018. Abandoned mine land reclamation-challenges and opportunities (holistic approach). In: Prasad MNV, de Campos Favas PJ, Maiti SK, editors. Bio-geotechnologies for mine site rehabilitation. Amsterdam: Elsevier. p. 3-31. doi:10.101 6/B978-0-12-812986-9.00001-4.
Fortoul T, Rodriguez-Lara V, Gonzalez-Villalva A, RojasLemus $\mathrm{M}$, Colin-Barenque L, Bizarro-Nevares P, García-Peláez I, Ustarroz-Cano M, López-Zepeda S, Cervantes-Yépez S, López-Valdez N, MeléndezGarcía N, Espinosa-Zurutuza M, Cano-Gutierrez G, Cano-Rodríguez M. 2015. Health effects of metals in particulate matter. In: Nejadkoorki F, editor. Current air quality issues. London: InTech. doi:10.5772/59749.

Gionfriddo C, Ogorek J, Butcher M, Krabbenhoft D, Moreau J. 2015. Mercury distribution and mobility at the abandoned Puhipuhi mercury mine, Northland, New Zealand. N Z J Geol Geop. 58(1):78-87. doi:10.1080/ 00288306.2014.979840.

Gray JE, Crock JG, Fey DL. 2002. Environmental geochemistry of abandoned mercury mines in West-Central Nevada, USA. Appl Geochem. 17(8):1069-1079. doi: 10.1016/S0883-2927(02)00004-5.

Gray JE, Greaves IA, Bustos DM, Krabbenhoft DP. 2003. Mercury and methylmercury contents in mine-waste calcine, water, and sediment collected from the Palawan Quicksilver mine, Philippines. Environ Geol. 43(3):298-307. doi:10.1007/s00254-002-0626-8.

Hasheela I, Schneider GI, Ellmies R, Haidula A, Leonard R, Ndalulilwa K, Shigwana O, Walmsley B. 2014. Risk assessment methodology for shut-down and abandoned mine sites in Namibia. J Geochem Explor. 144(PC):572580. doi:10.1016/j.gexplo.2014.05.009.

Hillegonds DJ, Wassenaar L, Klaus P, Aggarwal P. 2014. Synthesis report: intercomparison test for the determination of low-level tritium activities in natural waters for age dating purposes (TRIC2012). Vienna: International Atomic Energy Agency. http://www-naweb.iaea.org /napc/ih/IHS_programme_ihl_tric.html.

Holden WN. 2012. Ecclesial opposition to large-scale mining on Samar: neoliberalism meets the church of the poor in a wounded land. Religions. 3(3):833-861. doi: 10.3390/rel3030833.

Lanot JL, Lawig JAL, Lecaros JA, Malagotnot PJL, Labay PM, Samaniego JO. 2020. Physico-chemical properties and heavy metal contents of Ino-capayang mine-made lake in Marinduque, Philippines. Int J Eng Res Technol. 13(6):1493-1496.

Lim HS, Lee JS, Chon HT, Sager M. 2008. Heavy metal contamination and health risk assessment in the vicinity of the abandoned Songcheon Au-Ag mine in Korea. J Geochem Explor. 96(2-3):223-230. doi:10.1016/j.gexp lo.2007.04.008.

Matisoff G. 2014. 210Pb as a tracer of soil erosion, sediment source area identification and particle transport in the terrestrial environment. J Environ Radioact. 138:343354. doi:10.1016/j.jenvrad.2014.03.008.

Motzer W. 2007. Tritium age dating of groundwater. HydroVisions. 16(2):5,23. https://www.grac.org/media /files/files/388022b0/Summer_2007.pdf.

Qiu G, Feng X, Wang S, Shang L. 2005. Mercury and methylmercury in riparian soil, sediments, mine-waste calcines, and moss from abandoned $\mathrm{Hg}$ mines in east Guizhou province, southwestern China. Appl Geochem. 20(3):627-638. doi:10.1016/j.apgeochem.2004.09.006.

Qiu G, Feng X, Wang S, Shang L. 2006. Environmental contamination of mercury from $\mathrm{Hg}$-mining areas in Wuchuan, northeastern Guizhou, China. Environ Pollut. 142(3):549-558. doi:10.1016/j.envpol.2005.10.015.

Samaniego J, Gibaga CR, Tanciongco A, Rastrullo R. 2020. Total mercury in soils and sediments in the vicinity of abandoned mercury mine area in Puerto Princesa City, 
Philippines. Appl Sci. 10(13):4599. doi:10.3390/app101 34599.

Samaniego JO, Gibaga CRL, Tanciongco AM, Rastrullo RM, Costa MAV. 2019. Surface water characteristics in the vicinity of abandoned mercury mine site in Puerto Princesa City, Philippines. Philipp J Sci. 148(3):493-498. http://philjournalsci.dost.gov.ph/94-vol-148-no-3-s eptember-2019/1076-surface-water-characteristics -in-the-vicinity-of-abandoned-mercury-mine-sitein-puerto-princesa-city-philippines.

Sprovieri F, Pirrone N, Ebinghaus R, Kock H, Dommergue A. 2010. A review of worldwide atmospheric mercury measurements. Atmos Chem Phys. 10(17):8245-8265. doi:10.5194/acp-10-8245-2010.

[US EPA] United States Environmental Protection Agency.
2002. Supplemental guidance for developing soil screening levels for superfund sites. Washington (DC): Office of Emergency and Remedial Response.

[US EPA] United States Environmental Protection Agency. 2011. Exposure factors handbook 2011 edition (final) Washington (DC): Office of Emergency and Remedial Response.

[US EPA] United States Environmental Protection Agency. 2019. TENORM: copper mining and production wastes. https://www.epa.gov/radiation/tenorm-copper-mi ning-and-production-wastes.

Wang L, Ji B, Hu Y, Liu R, Sun W. 2017. A review on in situ phytoremediation of mine tailings. Chemosphere. 184:594-600. doi:10.1016/j.chemosphere.2017.06.025. 